\title{
The Stepmother-Stepchild Dyad: Narratives in the Remarriage Context
}

\author{
Cristina Ribeiro Dantas - Pontifícia Universidade Católica do Rio de Janeiro, Rio de Janeiro, Brasil \\ Terezinha Féres-Carneiro - Pontifícia Universidade Católica do Rio de Janeiro, Rio de Janeiro, Brasil \\ Rebeca Nonato Machado - Pontifícia Universidade Católica do Rio de Janeiro, Rio de Janeiro, Brasil \\ Andrea Seixas Magalhães - Pontificia Universidade Católica do Rio de Janeiro, Rio de Janeiro, Brasil
}

\begin{abstract}
The present study is part of a wider research about conjugality and parenthood in remarriage and aims to investigate the perception of stepmothers about their relationship with their stepchildren. For that, a qualitative research was carried out, in which 16 stepmothers of the middle socioeconomic segment, aged 28 and 43 years, were interviewed. The results were analyzed according to the content analysis method in its categorical aspect. Six categories of analysis emerged from the material. In order to achieve the objectives formulated in this study, the category stepmother-stepchild dyad, divided into two subcategories: bonding with the stepchildren and participation in education will be discussed. It was observed that the relationship between the stepmother and her stepchildren, besides being built gradually, is crossed by the father and the mother who authorizes or shies away the bond between the stepmother-stepchild dyad.

Keywords: stepmother, stepchild, remarriage, father, mother.
\end{abstract}

A Díade Madrasta-Enteado: Narrativas no Contexto do Recasamento

\begin{abstract}
Resumo
O presente estudo é parte de uma investigação mais ampla sobre a conjugalidade e a parentalidade no recasamento e tem como objetivo investigar a percepção das madrastas acerca da sua com relação com seus enteados. Para tanto, realizou-se uma pesquisa qualitativa, na qual foram entrevistadas 16 madrastas do segmento socioeconômico médio, com idades entre 28 e 43 anos. Os resultados foram analisados de acordo com o método de análise de conteúdo na sua vertente categorial. Da análise do material, emergiram seis categorias de análise. Para atingir os objetivos formulados nesse trabalho, será discutida a categoria díade madrasta-enteado desdobrada em duas subcategorias: construindo o vínculo com os enteados e participação na educação. Constatou-se que a relação entre a madrasta e seus enteados, além de ser construída gradualmente, é perpassada pelo pai e pela mãe que autorizam ou coíbem o vínculo entre os membros da díade madrasta-enteado.

Palavras-chave: madrasta, enteado, recasamento, pai, mãe.
\end{abstract}

La Díada Madrastra-Hijastro: Narrativas en el Contexto del Recasamiento

\section{Resumen}

El presente trabajo és parte de una investigación amplia sobre laconyugalidad y la parentalidad en el recasamiento cuyo objetivo es investigar la percepción de las madrastas acerca de la relación entre madrastas y sus hijastros. Para esto, se realizó una encuesta cualitativa en la cual fueron entrevistadas 16 madrastras del segmento socioeconómico medio, con edades entre 28 y 43 años. Los resultados fueron evaluados usando el método de análisis de contenido en su vertiente categorial. De la evaluación de material emergieron seis categorías de análisis. Este trabajo irá discutir la categoría díada madrastra-hijastro, desplegada en dos subcategorías: construyendo el vínculo con los hijastros y participación en la educación. Se constató que la relación entre madrastras y hijastros, además de ser construida gradualmente, es atravesada por el padre y por la madre, que autorizan o cohíben el vínculo entre los miembros de la díada.

Palabras clave: madrastra, hijastro, recasamiento, padre, madre

The high rates of divorce, consensual unions and remarriages have contributed to the emergence of new family dynamics. According to Giddens (1993), the most important changes that have been taking place in contemporary society concern personal life, gender roles, sexuality, marriage and the family. However, despite the numerous transformations and plurality of family configurations currently contemplated, the family continues to exist as an affective group, enabling the generational transmission of values, beliefs and emotions, as well as being a strong mediator between the individual and society (Féres-Carneiro, Ponciano \& Magalhães, 2007).

According to Zordan, Wagner and Mosmann (2012), the fact that contemporary society is less conservative allows the subjects to accept different styles more naturally Among them, we list: to be single, to divorce, to marry several times, to have a relationship with a person of the same sex or to choose not to have children. In this context, the transformations that the family has been going through, refer, among other aspects, to its configuration and structure. 
The remarriage begins a new stage in the life of that family group, generating changes in the routine and in the interaction of its members. The passage from the 'we' of the first marriage family, or of the previous marriage, to the 'we' of the remarriage, does not occur immediately. Papernow (2013) suggests a period of adaptation, ranging from two to four years, to create the identity of that family group, adding three aspects that favor the feeling of belonging. The first arises from the similar interests and values shared among the subjects. The second aspect tends to occur gradually and refers to patterns of behavior, habits and rituals built together by members of the remarried family. And finally, the third occurs when differences need to be negotiated and legitimized.

The period of adaptation of all subjects to the remarriage takes time, as observed in several studies. While McGoldrick and Carter (2001) and Papernow (2013) claim it takes two to four years, Hetherington and Kelly (2002) suggest a period of adaptation ranging from five to seven years. According to these considerations, resilience, flexibility and adaptability become fundamental to creating a family identity (Costa \& Dias, 2012; Papernow, 2013).

The remarriage provokes a restructuring of the patterns of relationship between family members regarding roles, responsibilities, changes in routine, financial arrangements and cohabitation, among others. Although marital ties have been broken and then redone, parental ties from the previous relationship remain, as parents remain responsible for the upbringing and care of their children.

Conjugality and parenthood are two dimensions that constitute the family psyche, where generational contents, identification models and ideals of the family are transmitted (Magalhães \& Féres-Carneiro, 2011). Conjugality refers to the shared identity between spouses, the plans, projects and dreams in common, that is, it corresponds to the story created by the couple. Parenting is a process in permanent construction, that demands a series of adaptations inherent to the new roles and responsibilities of the couple. According to Hintz and Baginski (2012), the transition from the conjugal subsystem to the parental subsystem propitiates changes in the conjugal dynamics, altering the previous organization of the couple.

When it comes to remarriage, the stepmother, the stepfather, their children and the birth of the children of the new unions point to the interweaving of several conjugal and parental subsystems, making the interplay between conjugality and parenthood even more complex (Silva, Trindade \& Silva Junior, 2012). The subject who remarries and has children of previous relationships, can come to play the parental roles with both his ex-spouses and his current companions, thus expanding the parenthood (Magalhães, Féres-Carneiro, Henriques \& Travassos-Rodriguez, 2013).

The term co-parenting emerged in the 1970s to encompass the exercise of parental functions after divorce (Ahrons, 1981). It is worth noting that this term is not applied only in cases of divorce, but is also used to address the negotiation between the parents in cooperation for the education of their children. Madden-Derdich and Leonard (2002) began to mention co-parenting when studying the interaction between ex-spouses in decisions concerning their children.

Co-parenting can be thought of as an interplay of caregiving roles for children, not restricted to single parents, married or separated, including situations in which two adults share parental roles, negotiating their roles and responsibilities to promote the emotional health of children/stepchildren. Thus, the stepmother who participates in the care and education of the stepchildren, imposing rules and limits, exercises co-parenting by assuming parental responsibilities with her husband.

In the remarriage, the increase in the number of people involved in the care of the children/stepchildren is observed, and may represent an opportunity, not only for the new couple, but also for the children/stepchildren to create new bonds. Researching the way in which the affection bonds in the stepmother-stepchildren dyad are constructed, as well as the co-parenting arrangements, can promote reflections on the challenges and potentials round the members of this dyad. The expansion of knowledge about the relationship between stepmothers and stepchildren can contribute to the understanding of the functioning of remarried families, providing subsidies to the professionals who deal with them. Considering the importance of this theme for the health of the familial environment, the present study aims to investigate, from the perception of stepmothers, the relationship between themselves and their stepchildren.

\section{Method}

\section{Participants}

Sixteen stepmothers, resident in the city of Rio de Janeiro and belonging to the middle classes of the 
population, participated in this study. The definition of middle class used in this work goes beyond the concept of social class that is based solely on family income, corresponding, therefore, to something more comprehensive and complex, taking into consideration also similarities such as access to knowledge, schooling, cultural capital, among others (Velho, 1987).

The age of the stepmothers ranged from 28 to 43 years $(\mathrm{M}=36.7, \mathrm{SD}=4.6)$. The remarriage time ranged from 3 to 14 years $(M=6.3, S D=3.2)$. Of the 16 stepmothers, ten reside with at least one stepchild; three spend at least one day a week with their stepchildren, and alternating weekends; and three meet with the stepchildren on weekends every 15 days. Table 1 presents the description of the participants' profile.

\section{Instrument}

As a research tool, interviews were recorded in audio and later fully transcribed. The semi-structured script of the interviews was formulated based on a review of the literature on the subject, with open questions, elaborated based on the following thematic axes: construction of the place of the stepmother; the social imaginary about the stepmother; experience of conjugality in the remarriage; building the bond with the stepchildren; relationship with the mothers of the stepchildren.

\section{Procedures}

The research project was approved by the Ethics Committee (No. 2014-08) of the university where it was developed. We found the participants either through personal acquaintances or through indication of the interviewees themselves, thus constituting a convenience sample. The interviews lasted from one to three hours and the place, date and time were scheduled according to the availability of the stepmothers. All of them signed the Free and Informed Consent Term, authorizing the dissemination of results in teaching, research and publication, and were informed that their identity and that of their family members would be preserved.

Table 1

Biographic characteristics of the interviewed stepmothers

\begin{tabular}{|c|c|c|c|c|c|c|}
\hline \multirow[t]{2}{*}{ Stepmother } & \multirow[t]{2}{*}{ Age } & \multirow{2}{*}{$\begin{array}{c}\text { Remarriage time } \\
\text { (years) }\end{array}$} & \multicolumn{2}{|c|}{ Stepchildren } & \multicolumn{2}{|c|}{ Children } \\
\hline & & & quantity & age & quantity & age \\
\hline M1 & 34 & 8 & 1 & 17 & 1 & 1 \\
\hline M2 & 43 & 7 & 1 & 11 & 1 & 3 \\
\hline M3 & 43 & 3 & 3 & $27 ; 20 ; 15$ & 2 & $11 ; 3$ \\
\hline M4 & 39 & 6 & 1 & 13 & 2 & $5 ; 3$ \\
\hline M5 & 28 & 9 & 1 & 12 & - & - \\
\hline M6 & 40 & 2 & 5 & $31 ; 30 ; 16 ; 15 ; 9$ & - & - \\
\hline M7 & 36 & 2 & 1 & 13 & 1 & 1 \\
\hline M8 & 38 & 3 & 1 & 12 & - & - \\
\hline M9 & 28 & 6 & 2 & $16 ; 10$ & 1 & 1 \\
\hline M10 & 38 & 14 & 2 & $24 ; 15$ & 1 & 11 \\
\hline M11 & 41 & 8 & 2 & $16 ; 11$ & - & - \\
\hline M12 & 31 & 5 & 1 & 15 & 1 & 1 \\
\hline M13 & 37 & 6 & 2 & $17 ; 15$ & 1 & 2 \\
\hline M14 & 39 & 7 & 1 & 17 & 1 & 2 \\
\hline M15 & 37 & 11 & 1 & 12 & - & - \\
\hline M16 & 35 & 4 & 1 & 7 & 1 & 1 \\
\hline
\end{tabular}




\section{Data Analysis}

The collected data were submitted to a content analysis method, in its categorial aspect, with the purpose of investigating, from the discursive material, the meanings the respondents attributed to the phenomena (Bardin, 2011). By means of the categorial technique, theme categories were highlighted, organized from the similarity between the elements contained in the material. For this, a "floating reading" was carried out, grouping significant data, identifying and relating them, until the categories of analysis were highlighted.

This work presents part of the results of a broader research, in which the objective was to investigate conjugality and parenthood in the remarriage, based on the experience of the stepmothers. From the narratives of the participants, six categories of analysis emerged: place of the stepmother in the family; the name "stepmother"; conjugality in remarriage; stepmother-stepchild dyad; stepmother-stepchild-mother triad; and generational transmission. In order to achieve the objectives formulated in this study, the category stepmother-stepchild and its subcategories will be discussed. The other categories were discussed in other published works. To present the results, the stepmothers were named from one to 16 , and then the age of each one was added.

\section{Results and Discussion}

\section{Stepmother-stepchild dyad}

Recent studies suggest that the fear of being rejected by the stepchildren, as well as building and maintaining relationships with them, are among the greatest challenges faced by stepmothers (Doodson, 2014, Papernow, 2013, Pryor, 2014). Among the concerns they have about their stepchildren, Doodson (2014) points out the following: the desire to be accepted by them, the lack of knowledge about the role of the stepmother, the questioning about their parental skills and the relative divergences between the rules and values that permeate the education of stepchildren. In fact, the entry of the stepmother into the remarried family may require reorganizations with regard to parental functions, besides raising new outlines in the family subsystems. From the narratives of the stepmothers, the stepmother-stepchild dyad category was divided into two subcategories: building the bond with stepchildren; and participation in education.

\section{Building the bond with stepchildren}

Most stepmothers claim to have a good relationship with their stepchildren. The bonding is understood as a process, possibly strengthened with the passage of time and the recognition of the otherness of the subjects, fundamental factors for the constitution of the bond between stepmothers and stepchildren.
"We (stepmother and stepchildren) have a very nice relation- ship and it was a slow, respectful construction, without anyone invading the space of the other and I think that was very important, going slowly, knowing that time plays in our favor and not against us" (stepmother 3, 43 years old).
"I think you have to expect a consistency in the relationship, you know? An achievement too. Calm ... You have to be calm to establish a relationship and then yes, you can act naturally" (stepmother 11, 41 years).

The narratives of the stepmothers, emphasizing the time and calm related to the constitution of the bond with the stepchildren, are antagonistic to the myth of 'instant love', according to which it is expected that the subjects involved in the remarriage begin to relate in a harmonious and immediate way (Grisard Filho, 2010). In this myth, the spouses believe that the feeling that united them must be shared, instantly, by all. However, waiting for the subjects to create affective bonds quickly, opposes the time and investment necessary to adapt and build the bonds in the remarried family (Costa \& Dias, 2012; Soares, 2015). The narratives suggest resilience and conviviality with stepchildren as aspects capable of fostering the emergence of relationships that promote emotional health. From the interviews, it was verified that the period of adaptation of the stepmothers to the remarriage took at least three years.

"I can say that the adaptation period lasted about three years ... It was an adaptation ... Sometimes I thought, when would I start to enjoy it, you know? Because although I played with them (stepchildren) ... I was tired ... But I think it was all the change, you know?" (stepmother 11, 41 anos).

Valentim de Sousa and Dias (2014) point out that, after the period of adaptation of the subjects in the remarried family, stepchildren showed a good relationship with their step-parents. The authors affirm that the construction of the affective bond between stepparents and stepchildren occurs when stepmothers / stepfathers initially interact with their stepchildren in a non-intrusive way, trying to avoid interfering in the relationships established previously. In this regard, we noticed a caution in the stepmothers to not invade the 
space of the husband with his children, ensuring the maintenance of the bond established between them.

"D. (busband) took W. (Stepdaughter) to Disney and I did not go, it was just them. I think they need their space... The first thing the child needs to know is that that space, with her father, will be preserved ... I think remarriage is an art"(stepmother 2, 43 years old).

The delimitation of spaces that comprise the different subsystems in the remarried family - parents and children, father and mother, stepmothers and husbands, stepmothers and stepchildren, stepmothers and the mothers of their stepchildren, stepmothers and their children, blood brothers, half-brothers and socio-affective siblings - brings out the need for renegotiations about roles, boundaries, privacy, time and space. We should emphasize that boundaries, not only outline the individuals, subsystems and the family system as a whole, but they also set the rules that define how and who participates in each family subsystem, aiming at protecting and differentiating of members in the family system (Minuchin, 1982; Wagner, Trunk \& Armani, 2011). In this matter, complexity in remarriage may be related, among other things, to the need for clearly delimited boundaries, since various levels of subsystems - conjugal, parental, fraternal - occur simultaneously, often spanning different homes.

Researching the establishment of links in the remarried family, Golish (2006) states that families capable of creating relationships that promote emotional health are those in which communication is fluid and effective, and the rules and boundaries are clear. In addition, in such families, the subjects are committed to seeking solutions to the problems and preserving the image of the father/mother who does not cohabit with their children.

Many narratives show parents having guilty feelings for inflicting a new family reality on their children. The data illustrates how the beginning of the new conjugal life interferes in the dynamics of the parent-children subsystem, demanding innovation in patterns of affective investment.

"When I first met W. (stepdaughter) everything was totally natural ... Separated, guilty parents, so the weekend was just for the child... When I met D. (busband), on his weekends, he would say, "W. what do you want to do?'I think it's normal because he really missed her... I think tha child has an opinion, yes, but she can not boss her parents" (stepmother 2, 43 years old).

\begin{abstract}
'I would say, 'everyone here is going to do the dishes' and he (busband) would say, 'my daughter won't', so that was very difficult. We did not have a model, no ... I think that, as he worked more on his guilt, he was able to assert himself more, it was easier" (stepmother 14, 39 years old).
\end{abstract}

The narratives demonstrate the parents' concern with their children and suggest that the parents' feelings of guilt over the changes imposed on the children can also affect the subsystem involving stepmothers and stepchildren, resonating in the relationship of the new couple. According to Kehl (2003), the nostalgia over the idealized traditional family can make the adult feel as if in debt to their children/stepchildren, making it difficult to maintain the position of responsible authority towards them.

Some stepmothers report that at the beginning they wanted to educate and set limits for the stepchildren, but when they came across the boundary imposed by the parents and their stepchildren, they needed to redefine their relationship with them. On this matter, Ganong, Coleman and Jamison (2011) affirm that 'changes in trajectory' is one of the patterns of relationship development between stepmothers and stepchildren.

\section{"At first I got very involved with them, I was more into the discipline, scolding, you know? And it did not work. Even my husband did not like it. He even said, 'You are not their mother"” (stepmother 13, 37 years old). \\ "When D. (stepson) says" Ab, you are not my mother", be (busband) says: 'But she is the lady of the house, you have to respect this, the choice is not yours', and D. resents this, he says: 'you're on her side'. But it is not a matter of sides" (stepmother 10, 38 years old).}

The narratives suggest interdependence between the parental and conjugal subsystems, demonstrating the importance of flexibility and emotional availability of the stepmothers to readapt to the different contexts and roles. Thus, while the boundaries between parenthood and conjugality need to be well discriminated, they also need to be flexible to address the specific needs of each family (Suanet, Van Der Pas \& Tilburg, 2013). In this study, stepmothers say they have learned, in living with the stepchildren, the best way to deal with them.

Among the stepmothers who have had children with their current husbands, many claim that the birth of a stepbrother took them out of the status of 'foreigners of the family', favoring their sense of belonging. In agreement with previous studies, the statements 
suggest that the birth of the stepbrother legitimizes more concretely the insertion of the stepmother in the remarried family (Amaral \& Dias, 2011, Oliveira, 2005; Valentim de Sousa \& Dias, 2014).

"I think B. (son of this remarriage) came to gather everyone, even more so for me, because their family never ceased to exist. I felt like the father's wife, so when it came to using the space in the house, I was very inhibited to occupy that space, but when B. was born, then I think I felt more participant" (stepmother 13, 37 years).

"I think that with the birth of $\mathrm{R}$. (daughter of this remarriage) I stopped being the foreigner, I think this piece of the father that is with me is what unites everyone, including me. I also feel more sure with this blood thing. And I see $V$. (stepdanghter) different. I do not want, by any means, that my daughter does not have a good relation with her sister" (stepmother 14, 39 years).

Although the birth of the half-brother has generated changes, re-adaptations, initial conflicts, competition for the love of the parent and jealousy in stepchildren, the participants point out that these feelings have been transformed, making possible the creation of fraternal bonds. In addition, stepmothers admire and support the relationship built between their children and stepchildren.

"When I got pregnant, B. (stepdaughter) felt a little ... she got really beat up, she was like, ah, you will not like me anymore... And she was 11 already ... And she was a little surprised, so she cried. At home she shares the bedroom with my son every 15 days, so she kept marking the territory, kept counting how many photos there were of $A$. (son) how many pictures there were of her... But it is over, it was just at the beginning ... She was a little resistant with him (half-brother) ... But now she is in love with him and he adores her" (stepmother 7,36 years old).

In agreement with the research by Valentim de Sousa and Dias (2014), we noticed that, despite the changes experienced in the fraternal subsystem of the remarried family, the passing of time and the conviviality between them allowed the construction of strong affective bonds. The authors suggest that the adaptation to remarriage demands flexibility, patience, negotiation and respect.

\section{Participating in the education}

Most stepmothers claim to actively participate in the upbringing of stepchildren by setting rules and limits once they live with them. Even those who do not participate directly in education, claim to express their views on the subject with their husbands. Some interviewees suggest the need for the couple to establish a parental alliance to decide on issues about the children.

"I think it's necessary that I can educate. We live in the same house ... Educating is a part of loving ... I learned that D. (father) and I need to have an alliance, there is a hierarchy, they (son and stepdanghter) have their opinions, but we need to talk and have our alliance" (stepmother 2, 43 years old).

"My husband is participating more because I pointed out that he was leaving the upbringing of J. (stepson) all on me. I was the one who did everything; homework, study... When there was a wrong word he had to write it 50 times... I go to the school, I know the pedagogical counselors, these things" (stepmother 8,38 years old).

Establishing an alliance with the spouse or redefining parenting issues is in the narratives of stepmothers. Some speeches suggest that parental functions fall on the stepmothers, which calls of renegotiations between the couple. A research by Teixeira (2014) on the rules, routines and rituals in remarried families, points out that there is greater communication and coherence in educational practices among members of the remarried couple than between the separated parents. In addition to the co-parent alliance, it was noteworthy that the husband had to authorize the stepmother to perform parental duties.

"I think it will depend very much also on the father of the child, how be will let you take on that authority, of being almost a mother" (stepmother 16, 35 years old).

The husband may encourage or restrain the relationship between the stepmother and his children and, upon his permission, the relationship is formed in the stepmother-stepchildren's dyad. The relationship in this dyad is also influenced by how the mother accepts or rejects the stepmother, as observed in the participants' reports.

"Over time he (stepson) was opening a space for me, which I think has to do with the relationship I established with his mother, which is a very good relationship, a friendship even. At first, it was a strange thing, but then, I don't know, there she recognized that I wanted her son's good and then, she approached and facilitated this relationship" (stepmother 12,31 years ).

Psico-USF, Bragança Paulista, v. 23, n. 1, p. 37-46, jan./mar. 2018 


\begin{abstract}
"The girl (stepdanghter) was very good to me, but when I came to live here, she stopped talking to me, slammed the door in my face... She left for her mother's house... She took the pains of her mother... I think you have to have patience and tolerance because in the remarriage always comes a package, either the ex-wife or the ex-husband, the children" (stepmother 6,40 years).
\end{abstract}

The relationship between the stepmother and stepchild is influenced by the opinions and attitudes of the father and the mother, which facilitate or hinder the interaction dynamics between them. So husbands need to manage co-parenting, both with their current wives (stepmothers) and with their ex-wives (the mothers). When it comes to these interactions, Silva, Trindade and Silva Junior (2012) affirm that, in the new family composition, the mother will need to share the maternal functions when her children are under the care of the stepmother, requiring adults to redimension and constantly renegotiate parental roles.

Grzybowski (2011) argues that aspects that contributed both positively and negatively during the marriage continue to influence the separation and co-parenting. According to the author, the couple who can separate, while maintaining mutual respect, may be the one who can also establish rules that promote the well-being of their children. On the other hand, according to Wagner and Mosmann (2009), couples with a strong emotional conflict may not be able to separate the conjugality of parenting, making it difficult to promote the children's emotional health. In line with these considerations, Grzybowski and Wagner (2010) point out that conjugality and the bonds between parents and children permeate all themes related to co-parenting after the separation.

Researches have pointed to the ability of the remarried family to promote the emotional health of its members when the stepfather and stepmother bond with the stepchildren, leaving the father and mother to exercise parental authority. However, it is necessary to establish with clarity the limits of the authority that the stepfather and stepmother can exercise, to not disqualify or void the role of the step-parent (Costa \& Dias, 2012; Ganong et al., 2011; Magalhães et al., 2013, Papernow, 2013, Pryor, 2014, Schrodt \& Braithwaite, 2011).

Some interviews mention that stepchildren can adapt and deal well with the fact that in many cases the rules in the house of the stepmother and the husband are different from those established in the mother's house. Many stepmothers report admiring the stepchildren's discretion.

\begin{abstract}
"She (stepdaughter) makes this transition from going there and coming here, right? She makes this transition super well ... She doesn't carry personal information from one home to the other. She's super discreet... She has lived with us and spent the weekends with her mother and now she lives with her mother and spends the weekends with us. She deals well with all this and I think this is very cool about her" (stepmother 4, 39 years).
\end{abstract}

It should be noted that many participants claim to admire the ability of stepchildren to manage two homes with different routines and family members. In one house, for example, the stepson ceased to be an only child (while his parents were married), to becoming, for a time, the youngest son (when his mother remarried) of three socio-affective siblings, to finally becoming the fourth out of the five siblings (after the birth of his half-brother). We can see the children's ability to deal with different subjects, dynamics, customs, rituals, and habits when parental roles are effectively exercised and there are low levels of conflict between adults. Several studies have pointed out the ability of children to maintain healthy relationships with both the parents and the step-parents, following a cumulative rather than substitutive model (Ganong et al., 2011; Magalhães et al., 2013, Paperwell, 2013, Pryor, 2014, Schrodt \& Braithwaite, 2011).

With regard to making demands, when the rules are not followed and the limits are violated, most stepmothers use their husbands to take charge and reprehend the stepchildren. Even those who say they feel authorized to impose the limits, they say that they prefer this function to be exercised by the husband. Some stepmothers mention being very cautious to reprehend the stepchildren, punctuating how delicate the stepmother-stepchildren dyad is.

\footnotetext{
'T'm bad at reprehending. When I do, I'm already on the edge .... And with C. (stepdaughter) of course, I try not to get into this mood, by the way, I've never gotten close to it with her ... That's where it comes in, because it's not my daughter, I think I get more careful with certain things that I could demand, I see that I don't ... Then there are certain things that I avoid" (stepmother 1, 34 years old).

"I have every right to reprehend. E. (busband) will never antagonize me in front of him (stepson), but I prefer him to do it because otherwise I'll always be annoying one ... Since someone has to be the annoying one, it's going to be the father, because otherwise he'll have that image of me" (stepmother 5, 28 years old).
} 
Although many stepmothers feel responsible for the upbringing of stepchildren, most abstain from reprimanding them, fearing to taint the bond or cross the border of the parent-child subsystem. The establishment of clear and permeable limits, facilitating the movement of the subjects, as well as accepting and fulfilling parental responsibilities are aspects that promote emotional health in the remarried family (Mc Goldrick \& Carter, 2001).

From the results, we see the importance, emphasized by the stepmothers, to establish limits in relations with stepchildren, their mothers and their husbands, corroborating other studies about the uncertainties, fragilities and ambiguities that perpass the conquest and maintenance of the places and roles that stepmothers and stepfathers occupy in the remarried family (Ganong et al., 2011, Papernow, 2013, Pryor, 2014).

\section{Conclusion}

Contrary to the myth of instant love, in which the love that unites the new couple is expected to affect all subjects in the remarriage, the data from this study suggest that the affective bonds between stepmothers and stepchildren were built in a gradual, respectful and cautious manner in order not to invade the relationship between their husbands and stepchildren. Stepmothers, who from the beginning tried to educate stepchildren, needed to redirect this behavior, which required flexibility, resilience and sensitivity to modify the parental role, that was often idealized.

From the results, we realized that the participation of the stepmother in the education of stepchildren is something granted by the fathers. In addition, the stepmother-stepchild dyad is also influenced by whether or not the husband (father) feels guilty about the separation and the way he elaborates on that feeling. Co-parenting relationships - stepmother/husband and husband/ex-wife - have repercussions in building the bond between stepmothers and stepchildren. In this context, the establishment of clear boundaries, which discriminate the conjugal dimensions of the parents, allows the members of the family system to exercise their functions in a way that promotes the emotional health of the subjects in the remarriage.

Cohabitation invites the stepmother to a greater participation in the education of her stepchildren. Meanwhile, expressions like 'cautious', 'there is always a baggage in the remarriage' (ex-spouse and children) and 'you are not my mother' were seen in the narratives of the stepmothers, pointing to the feeling of insecurity and ambivalence when defining her place in the family. Such feelings can generate discomfort, but can also contribute to the construction of new bonds that enrich affective relationships in the remarried family.

Some reports say that the birth of the step-sibling made it possible for the stepmother to transform the feeling of being a foreigner by securing her place in the family. So the fraternal subsystem expands and places, often under one roof, consanguineous, socio-affective siblings and half-siblings. The narratives point to the existence of initial conflicts concerning changes in the family system, but suggest the emergence of links capable of providing a contingency to the members of the remarried family. Unlike the conjugal, intersubjective, bond, the parental intersubjective bond, consisting of the stepmother (now the half-brother's mother), her husband and son (half-brother to the stepson) emerges as an important object of study for future researches.

In addition, future studies should investigate the relationships between mother-stepmother, stepmother-husband, stepfather-father, stepfather-wife and ex-wife-ex-husband, to contribute to identify and discriminate the modes of interaction, furthering the knowledge about the construction of bonds between the members of the remarried family. We should highlight the need for new research in different socioeconomic contexts, given that this is a limitation of the present study.

The results point to the stepmother being very careful to not invade the border of the subsystems of father and children, and mother and children. We found that the construction of the ties between the stepmother and her stepchildren is based on their interactions with their parents and their stepmothers. From the renegotiation of roles and limits, the results of this study suggest the need for flexibility and creativity to deal with the diverse demands arising from remarriage, allowing the creation of unique relationships and emotionally healthy family dynamics.

\section{References}

Ahrons, C., R. (1981). The continuing coparental relationship between divorced spouses. American Orthopsychiatric Association, 51(3), 415-428. http:// dx.doi.org/10.1111/j.1939-0025.1981.tb01390.x

Amaral, D. H., \& Dias, C. M. S. B. (2011). O subsistema fraterno na família recasada. Aletheia, 34, 123-137. http://pepsic.bvsalud.org/scielo.php?pid=S141303942011000100010\&script=sci_arttext

Psico-USF, Bragança Paulista, v. 23, n. 1, p. 37-46, jan./mar. 2018 
Bardin, L. (2011). Análise de conteúdo. São Paulo: Edições 70.

Costa, J. M., \& Dias, C. M. S. B. (2012). Famílias recasadas: mudanças, desafios e potencialidades. Psicologia: Teoria e Pesquisa, 14(3), 72-87. http://pepsic.bvsalud.org/pdf/ptp/v14n3/v14n3a06.pdfd

Doodson, L. J. (2014). Understanding the factors related to stepmother anxiety: a qualitative approach. Journal of Divorce and Remarriage, 55, 645-667. doi:1 $0.1080 / 10502556.2014 .959111$

Féres-Carneiro, T., Ponciano, E., L.,T., \& Magalhães, A., S. (2007). Família e casal: da tradição à modernidade. In C. M. O. Ceverny, Ceneide (Org.). Família em movimento (pp. 23-36). São Paulo: Casa do Psicólogo.

Ganong, L. H., Coleman, M., \& Jamison, T. (2011). Patterns of stepchild-stepparent relationship development. Journal of Marriage and Family, 73, 396-413. doi:10.1111/j.1741-3737.2010.00814.x

Giddens, A. (1993). A transformação da intimidade: sexualidade, amor e erotismo nas sociedades modernas. São Paulo: UNESP.

Golish, T. (2006). Stepfamily communication strengths. Human Communication Research, 29(1), 41-80.doi: 10.1111/j.1468-2958.2003.tb00831.x

Grisard Filho, W. (2010). Famílias reconstituidas: novas uniões depois da separação. São Paulo: Revista dos Tribunais.

Grzybowski, L., S. \& Wagner, A. (2010) Casa do pai, casa da mãe: a coparentalidade após o divórcio. Psicologia: Teoria e Pesquisa, 26(1), 77-87. http://www. scielo.br/pdf/ptp/v26n1/a10v26n1

Grzybowski, L. (2011). Ser pai e ser mãe. Como compartilhar a tarefa educativa após o divórcio? In: A. Wagner (Cols.). Desafios psicossociais da família contemporânea (pp.112-122). Porto Alegre: Artmed.

Hetherington, E. M., \& Kelly, J. (2002). For better or for worse: divorce reconsidered ( $1^{\text {sted. }}$.) New York: W.W. Norton.

Hintz, H. C. \& Baginski, P. H. (2012). Vínculo conjugal e transição para a parentalidade: fragilidades e possíveis superações. Revista Brasileira de Terapia de Família, 4(1), 10-22.

Kehl, M. R. (2003). Em defesa da família tentacular. In: Groeninga, G. C. \& Pereira, R. C. (Coords.). Direito de família e psicanálise - rumo a uma nova epistemologia, (pp.163-176). Rio de Janeiro: Imago.

Madden-Derdich, D., \& Leonard, S. (2002). Shared experiences, unique realities: formerly married mother's and father's perceptions of parenting and custody after divorce. Family Relations, 51(1), 37-45. doi:10.1111/j.1741-3729.2002.00037.x

Magalhães, A. S., Féres-Carneiro, T., Henriques, C. R., \& Travassos-Rodriguez, F. (2013). O lugar do padrasto na clínica com famílias recasadas. In $\mathrm{T}$. Féres-Carneiro, (Org.). Casal e familia: transmissão, conflito e violência (pp.113-128). São Paulo: Casa do Psicólogo.

Magalhães, A. S. \& Féres-Carneiro, T. (2011). Em busca de uma conjugalidade perdida: quando a parentalidade prevalece. In T. Féres-Carneiro, (Org.). Casal e familia: conjugalidade, parentalidade e psicoterapia (pp.161-172).

McGoldrick, M., \& Carter, B. (2001). Constituindo uma família recasada. In McGoldrick, M.\& Carter, B. As mudanças do ciclo de vida familiar. Uma estrutura para a terapia familiar (pp.95-105). Porto Alegre: Artes Médicas.

Minuchin, S. (1982). Famílias, funcionamento e tratamento. Porto Alegre: Artes Médicas.

Oliveira, A. L. (2005). Irmãos, meio-irmãos e co-irmãos: a dinâmica das relaçôes fraternas no recasamento. Tese de doutorado, Pontifícia Universidade Católica de São Paulo, Brasil.

Papernow, P. (2013). Surviving and thriving in stepfamiliy relationships. What works and what doesn't. New York: Routledge.

Pryor, J. (2014). Stepfamilies: a global perspective on research, policy and practice. New York: Routledge.

Schrodt, P., \& Braithwaite, D. O. (2011). Coparental communication satisfaction, and mental health in stepfamilies. Personal Relationships, 18, 352-369. doi:10.1111/j.1475-6811.2010.01295.x

Silva, P. O. M., Trindade, Z. A., \& Silva Junior, A. (2012). As representações sociais da conjugalidade entre casais recasados. Estudos de Psicologia (Natal), 17(3), 435-443.

Soares, L.C.E.C. (2015). Pais e mães recasados: vivências e desafios no "fogo cruz̧ado" das relações familiares. Curitiba: Juruá. 
Suanet, B., Van Der Pas, S. \& Tilburg, T. G. V. (2013). Who is in the stepfamily? Change in stepparents' family boundaries between 1992-2009. Journal of Marriage and Family, 75, 1070-1083. doi: 10.1111/ jomf.12053

Teixeira, L. (2014). Regras, rotinas e rituais nas famílias reconstituídas. Dissertação de mestrado em Educação e Desenvolvimento Humano, Universidade Católica Portuguesa, Porto.

Valentim de Sousa, D. H. A., \& Dias, C. M. S. B. (2014). Recasamento: percepções e vivências dos filhos do primeiro casamento. Estudos de Psicologia (Campinas), 31(2), 191-201. doi: 10.1590/0103-166x2014000200005.

Velho, G. (1987). Individualismo e cultura. Rio de Janeiro: Jorge Zahar.
Wagner, A. \& Mosmann, C. (2009). A promoção da qualidade conjugal como estratégia de proteção aos filhos. In: T. Féres-Carneiro (Org.). Casal e familia: permanências e rupturas (pp.169-180). São Paulo: Casa do Psicólogo.

Wagner, A., Tronco, C., \& Armani, A. B. (2011). Os desafios da família contemporânea: revisitando conceitos. In: A. Wagner (Cols.). Desafios psicossociais da familia contemporânea (pp.19-35). Porto Alegre: Artmed.

Zordan, E. P., Wagner, A. \& Mosmann, C. (2012). O perfil de casais que vivenciam divórcios consensuais e litigiosos: uma análise das demandas judiciais. PSICO USF, 17(2), 185-194.

Recebido em: 03-05-2016

Reformulado em: 16-03-2017; 06-04-2017

Aprovado em: 12-04-2017

Sobre as autoras:

Cristina Ribeiro Dantas, PhD in Clinical Psychology from PUC-Rio, postdoctoral student in Clinical Psychology at PUC-Rio. Professor of the Lato Sensu Graduate Course in Couple and Family Psychotherapy at PUC-Rio. Couple and family Psychotherapist.

E-mail: c.r.dantas@hotmail.com

Terezinha Féres-Carneiro, PhD in Clinical Psychology from PUC-SP, PostDoc in Couple and Family Psychotherapy from Paris V University. Full Professor at the Department of Psychology at PUC-Rio. Professor and coordinator at the Lato Sensu Graduate Course in Couple and Family Psychotherapy at PUC-Rio. Couple and family Psychotherapist, CNPq Research Productivity Fellow.

E-mail: teferca@puc-rio.br

Rebeca Nonato Machado, PhD in Clinical Psychology from PUC-Rio, post-doctoral student in Clinical Psychology at PUC-Rio. Professor and supervisor at the Lato Sensu Graduate Course in Couple and Family Psychotherapy at PUC-Rio. Couple and family Psychotherapist.

E-mail:recanm@gmail.com

Andrea Seixas Magalhães, PhD in Clinical Psychology from PUC-Rio. Associate Professor at the Department of Psychology, PUC-Rio. Professor and supervisor at the Lato Sensu Graduate Course in Couple and Family Psychotherapy at PUC-Rio. CNPq Research Productivity Fellow.

E-mail: andreasm@puc-rio.br

Contato com as autoras:

Rua Marquês de São Vicente, 225

Gávea, Rio de Janeiro-RJ, Brasil

CEP: 22.453-900 